
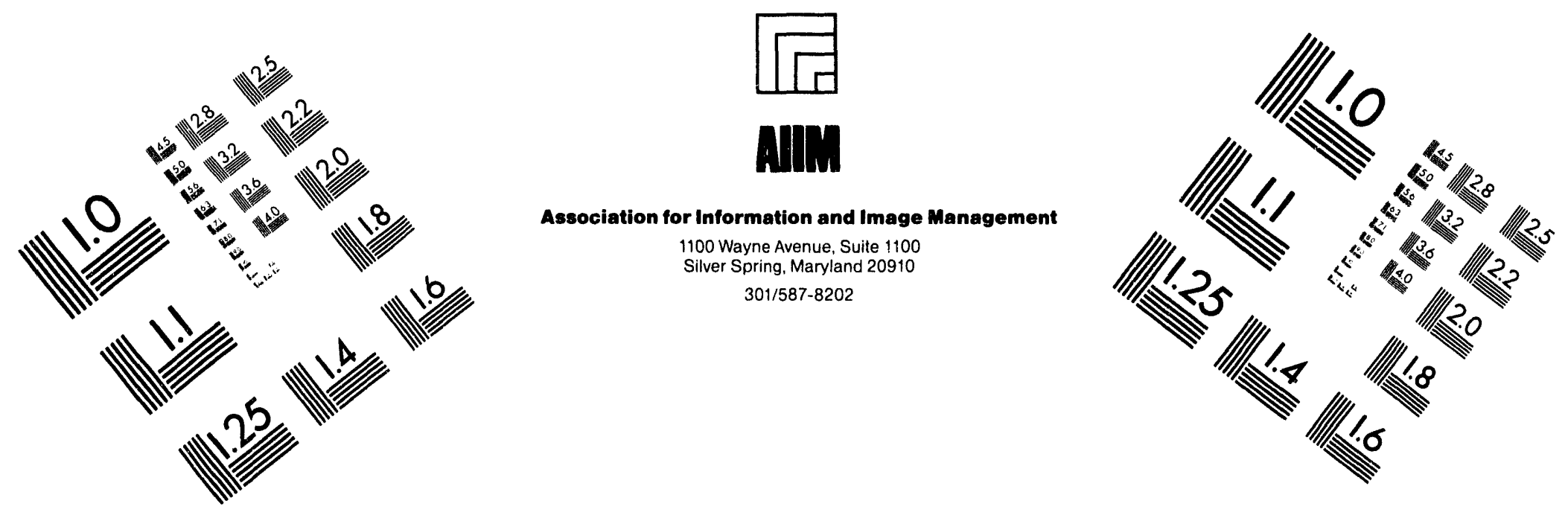

\title{
Centimeter
}

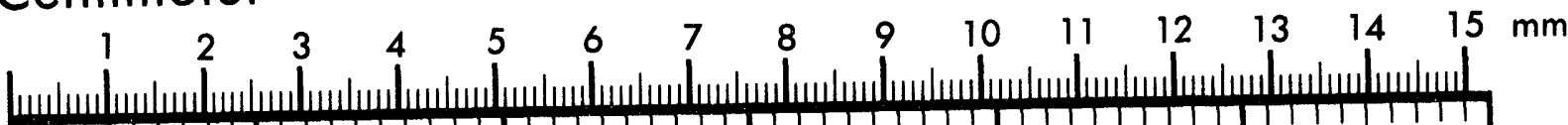

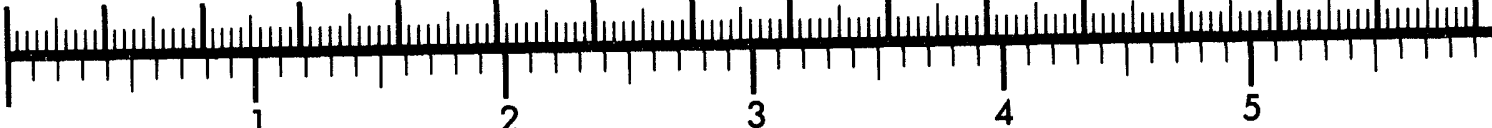
Inches
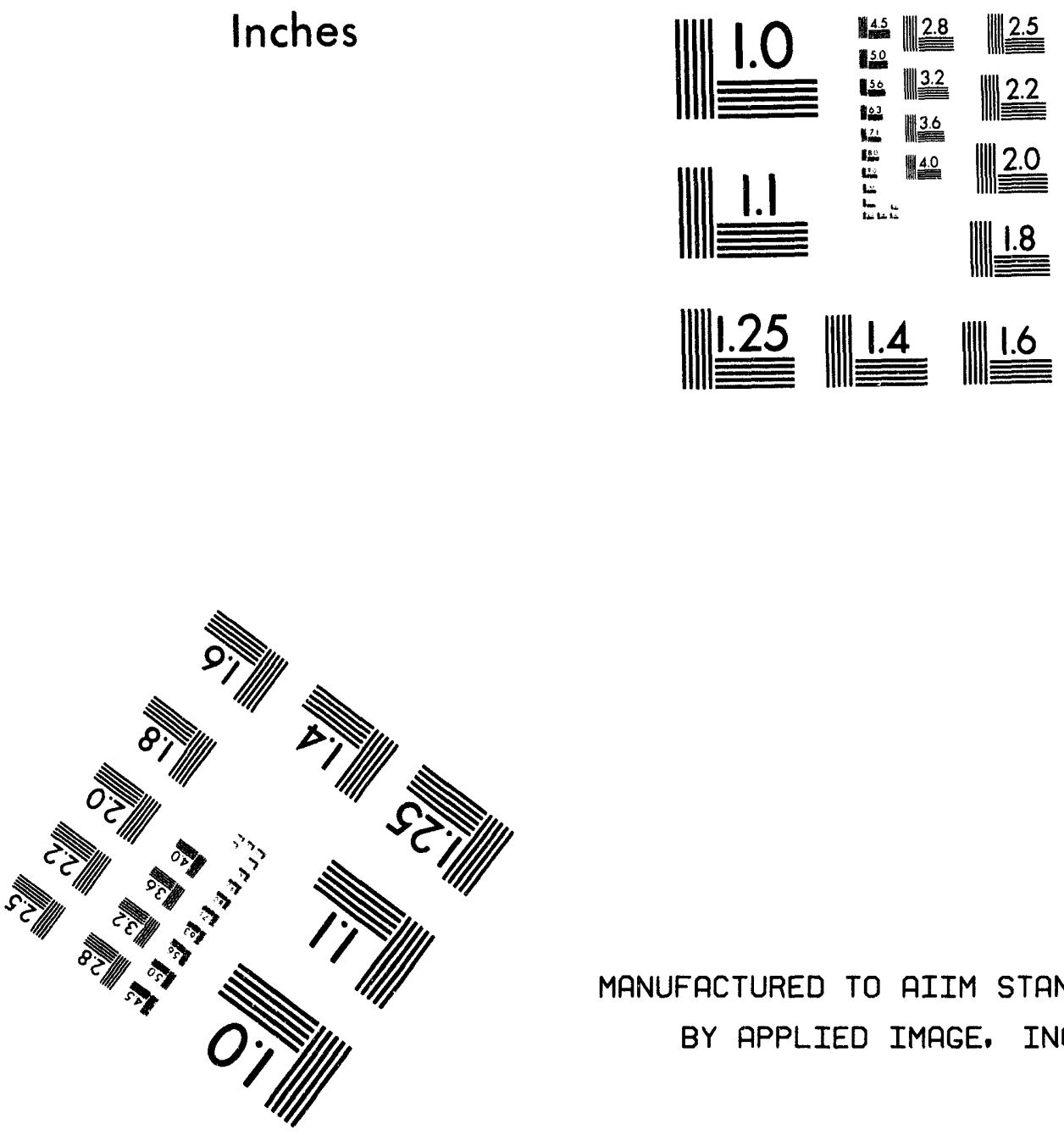

MANUFACTURED TO AIIM STANDARDS BY APPLIED IMAGE, INC.

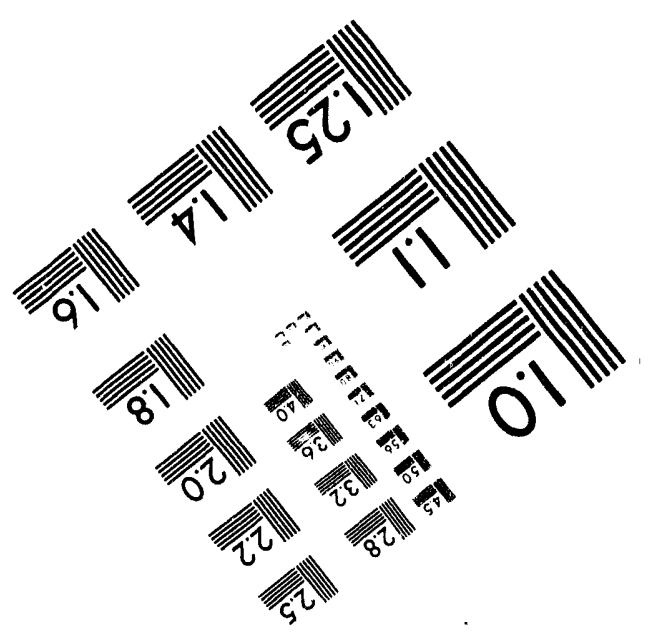



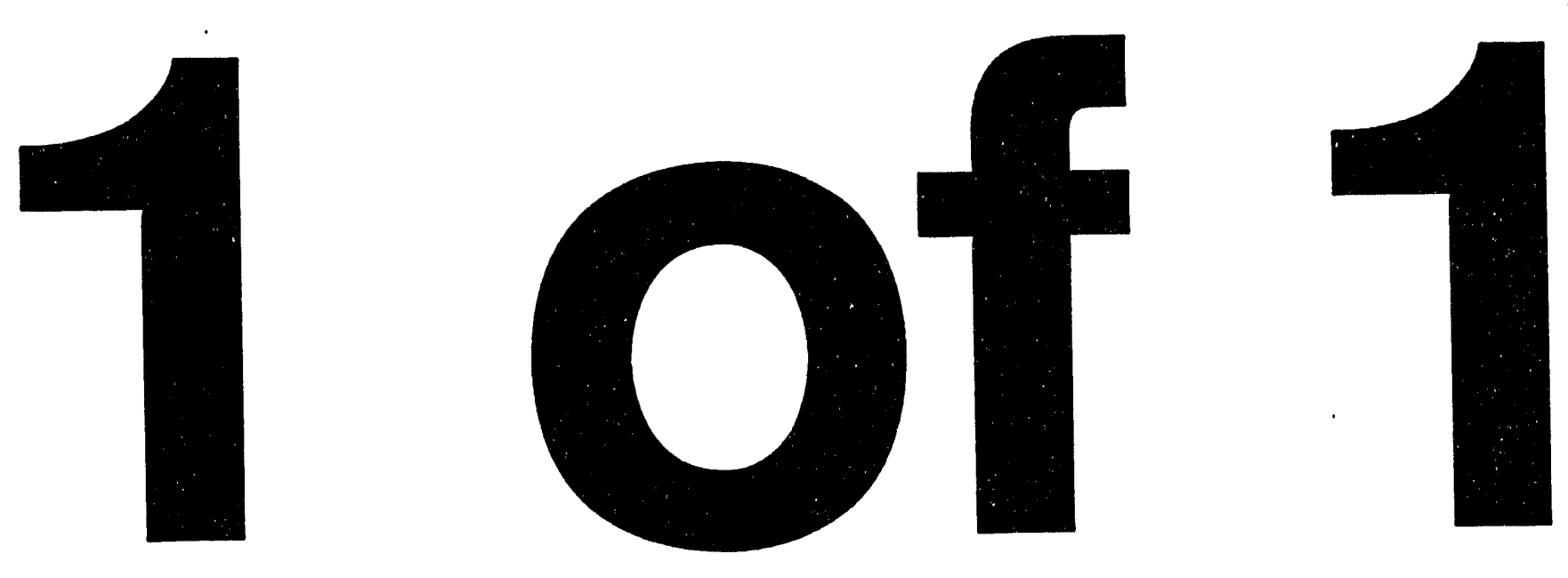


\section{SAVANNAH RIVER SITE ENVIRONMENTAL REPORT FOR 1993 SUMMARY PAMPHLET (U)}

by

Linda Karapatakis (contact)

Westinghouse Savannah River Company

Savannah River Site

Aiken, South Carolina 29808

DOE Contract No. DE-AC09-89SR18035

This paper was prepared in connection with work done under the above contract number with the $U$. $S$.

Department of Energy. By acceptance of this paper, the publisher and/or recipient acknowledges the U. S. Government's right to retain a nonexclusive, royalty-free license in and to any copyright covering this paper, along with the right to reproduce and to authorize others to reproduce all or part of the copyrighted paper. 


\section{DISCLAIMER}

This report was prepared as an account of work sponsored by an agency of the United States Government. Neither the United States Government nor any agency thereof, nor any of their employees, makes any warranty, express or implied, or assumes any legal liability or responsibility for the accuracy, completeness, or usefulness of any information, apparatus, product, or process disclosed, or represents that its use would not infringe privately owned rights. Reference herein to any specific commercial product, process, or service by trade name, trademark, manufacturer, or otherwise does not necessarily constitute or imply its endorsement, recommendation, or favoring by the United States Government or any agency thereof. The views and opinions of authors expressed herein do not necessarily state or reflect those of the United. States Government or any agency thereof.

This report has been reproduced directly from the best available copy.

Available to DOE and DOE contractors from the Office of Scientific and Technical Information, P. O. Box 62, Oak Ridge. TN 37831; prices available from (615) $576-8401$

Available to the public from the National Technical Information Service, U. S. Department of Commerce, 5285 Port Royal Rd., Springfield, VA 22161 


\section{Savannah River Site Environmental Report for 1993}

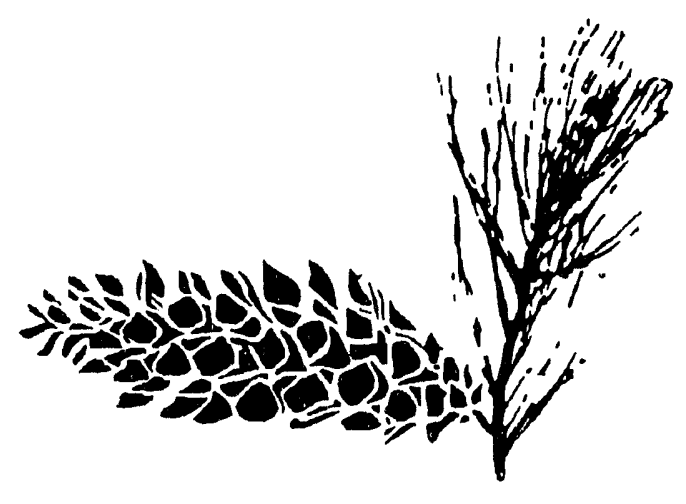

\section{Summary Pamphlet}

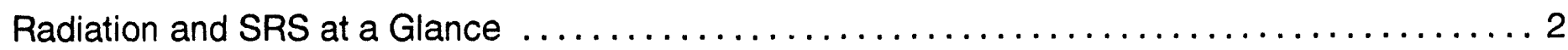

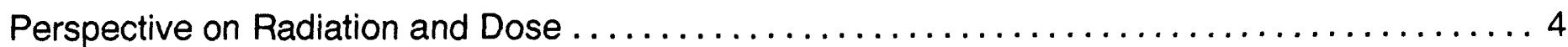

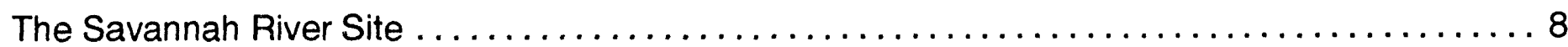

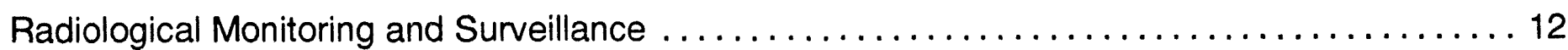
1993 Dose Estimates .............................................. 14

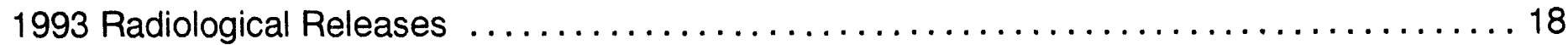

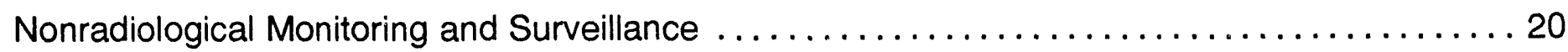

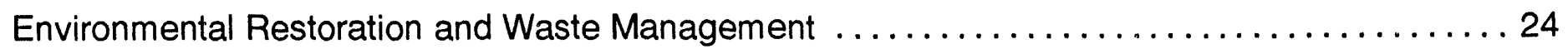

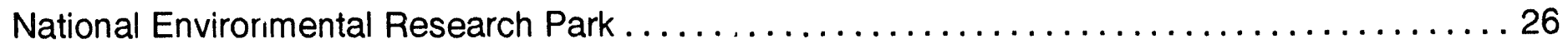

Environmental Monitoring Section

Environmental Protection Department

Westinghouse Savannah River Company

Savannah River Site

Aiken, SC 29808 
This document was prepared by the Westinghouse Savannah River Company under contract No.

DE-ACO9-89SR18035 with the United States of America, represented by the Department of Energy. Neither the United States Government nor Westinghouse Savannah River Company nor any of their employees makes any warranty, express or implied, or assumes any legal liability or responsibility for any apparatus, product, or process disclosed, or represents that its use would not infringe on privately owned rights. References herein to any specific commercial products, process, or service by trade name, trademark, manufacturer, or otherwise, does not necessarily constitute or imply its endorsement, recommendation, or favoring by the United States Government or Westinghouse Savannah River Company. 


\section{Summary Pamphlet Savannah River Site Environmental Report for 1993}

This pamphlet summarizes the impact of 1993 Savannah River Site (SRS) operations on the environment and the off-site public. It includes an overview of site operations; the basis for radiological and nonradiological monitoring; 1993 radiological releases and the resulting dose to the off-site population; and results of the 1993 nonradiological program.

The Savannah River Site Environmental Report for 1993 (WSRC-TR-94-075) describes the findings of the environmental monitoring program for 1993 . The report contains detailed information about site operations, the environmental monitoring and surveillance programs, monitoring and surveillance results, environmental compliance activities, and special programs. The report is distributed to government officials, members of the U.S. Congress, universities, government facilities, environmental and civic groups, the news media, and interested individuals. Copies of the report are placed in public reading rooms. For many people, this pamphlet will contain enough information; others may want to read the detailed report.

The data used to compile the annual environmental report and the summary pamphlet are published in a document titled Savannah River Site Environmental Data for 1993 (WSRC-TR-94-077). This publication is a collection of tables containing effluent monitoring data and environmental surveillance data for calendar year 1993. Complete data on groundwater can be found in the quarterly groundwater reports: first quarter (ESH-EMS-930096), second quarter (ESH EMS-930097), third quarter (ESH-EMS-930098), and fourth quarter (ESHEMS-930099).

The site also has a document ("SRS Environmental Monitoring Plan," WSRC-3Q1-2-1000) that describes effluent monitoring and environmental surveillance activities at SRS by identifying the rationale and design criteria for the monitoring program, the frequency of monitoring and analysis, specific analytical and sampling procedures, and quality assurance requirements.

To obtain copies of environmental reports and documents, contact

Manager, Environmental Publications

Westinghouse Savannah River Company

Building 735-16A

Aiken, South Carolina 29808

Telephone: $803-725-3556$ 


\section{Radiation and SRS at a Glance}

Of all activities at SRS, those associated with radiation receive the most attention. But, what exactly is radiation and where does it come from? To answer these questions, it is best to start with a few basics.

All matter is made up of extremely small particles called atoms. Atoms are bundles of even smaller particles called protons, neutrons, and electrons (figure 1). When an atom has the proper mix of protons and neutrons, it is stable, or nonradioactive. However, due to natural or man-made processes, some atoms do not have the proper mix of protons and neutrons. When this is the case, these unstable atoms break apart, or decay, in an attempt to become stable. As atoms decay, energy, or particles, are released. These releases are called radiation. But all radiation is not the same.

Some radiation has the ability to "knock" electrons off atoms. This process is known as ionization and produces ionizing radiation. Examples include X-rays and beta particles. Nonionizing radiation bounces off of or passes through matter without displacing electrons. Examples include visible light and radio waves. In the discussions that follow, the term "radiation" is used to describe ionizing radiation.

Radiation was not invented; it was discovered. It originates from natural events that happen all the time, but it can also be made by man. While there are sources of man-made radiation, most occurs naturally. While people can take some limited measures to reduce exposure to natural radiation, people cannot have no control over the amount that exists. In fact, the natural radiation present in the environment today is not much different than it was hundreds of years ago. Natural sources include uranium in the earth, radon in the air, and potassium in food.

Man-made sources of radiation include consumer products, medical procedures, and the nuclear industry. Some consumer products, such as smoke detectors, to-

Figure 1 Atoms: A Perspective

Atoms are made up of extremely smaller particles called protons, neutrons, and electrons. Think of an atom as a tiny solar system with a center of protons and neutrons circled by electrons. To visualize the relative size of the nucleus to the electrons, imagine a hydrogen atom with a nucleus the size of a baseball: its electrons would be a speck with an orbit wide enough to circle New York City.

Atoms are so tiny that about a hundred billion billion of them can fit on the head of a pin. Proportionally, an atom is to a ping pong ball what a ping pong ball is to the earth.

(Reference 1) 
bacco products and even porcelain dentures, either give off radiation or contain radioactive elements. Probably the most well-known source of man-made radiation is nuclear medicine. For example, to conduct a brain, liver, lung, or bone scan, doctors inject patients with radioactive compounds, then use special cameras to make a diagnosis by examining the resulting image of the organ. Even through radiation has been proven as a useful tool for man, it can be harmful.

The potential risk for damage from radiation is called dose. The larger the dose, the higher the potential for damage. A unit of measure known as a millirem, or mrem, is used to express dose. For example, a person receives a dose of about 2.5 mrem on a flight from New York City to Los Angeles. Whether natural or manmade, radiation has the same effect on people.

When properly managed and controlled, radiation is an efficient resource with many benefits. However, as with many industrial operations, the potential to harm people does exist. At SRS where man-made nuclear materials are handled and produced, much is done to control the exposure to radiation. Many safety measures are in place and very strict rules exist to protect workers and the people who live around the site. In spite of all these measures, small releases of radiation occur during routine operations.

In 1993, the largest estimated dose any single off-site individual could have received from SRS operations is estimated to be XXX mrem. To put this number into perspective, consider other contributors to the do 3 of the surrounding population (figure 2). The dose from site operations is a small fraction of the dose to the residents in the area surrounding SRS. Everyone receives a dose from radiation regardless of SRS operations.

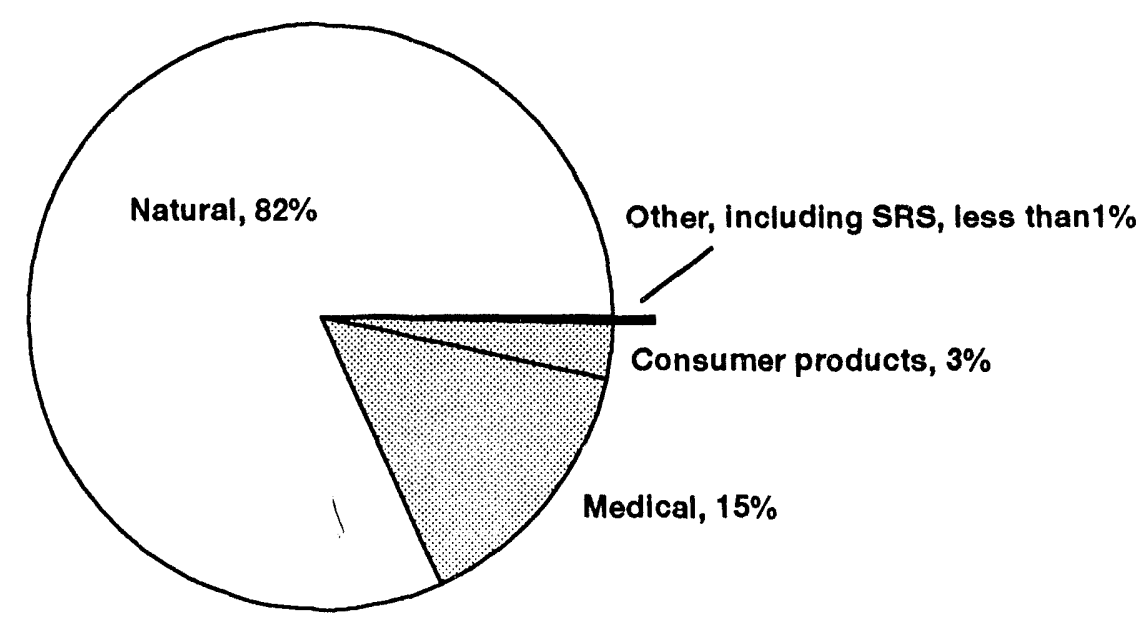

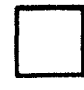

Natural

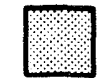

Man-made
Figure 2 Contributions to Individual Dose SRS operations contributed less than $1 \%$ to the average 1993 dose to the off-site public in the area surrounding SRS. 


\section{Perspective on Radiation and Dose}

Radiation, or radiant energy, is energy in the form of waves or particles moving through space. Visible light, heat, and radio waves are examples of radiation. When people feel warmth from the sunlight, they actually are absorbing the energy emitted by the sun.

\section{Natural Radiation}

Sources of natural, or background, radiation include internal radiation from food, cosmic radiation from the sun and from outside the solar system, and terrestrial radiation from the earth's rocks, soils, and minerals (figure 3). Exposure to natural radiation varies greatly depending on individual lifestyle, such as where a person lives and what materials are used to build a house. Natural radiation is categorized as cosmic, terrestrial, or internal depending on its origin.

Cosmic Radiation Cosmic radiation originates in outer space. Because the atmosphere provides some shielding against it, the intensity of this radiation increases with altitude above sea level: a person in Denver, Colorado, is exposed to more cosmic radiation than a person in Death Valley, California.

Terrestrial Radiation Terrestrial radiation refers to radiation emitted from radioactive materials in the earth's rocks, soils, and minerals.

Internal Radiation Radiation in the environment enters the body with the air people breath and the foods they eat (everyone has approximately 500,000 atoms disintegrating in their bodies every minute).

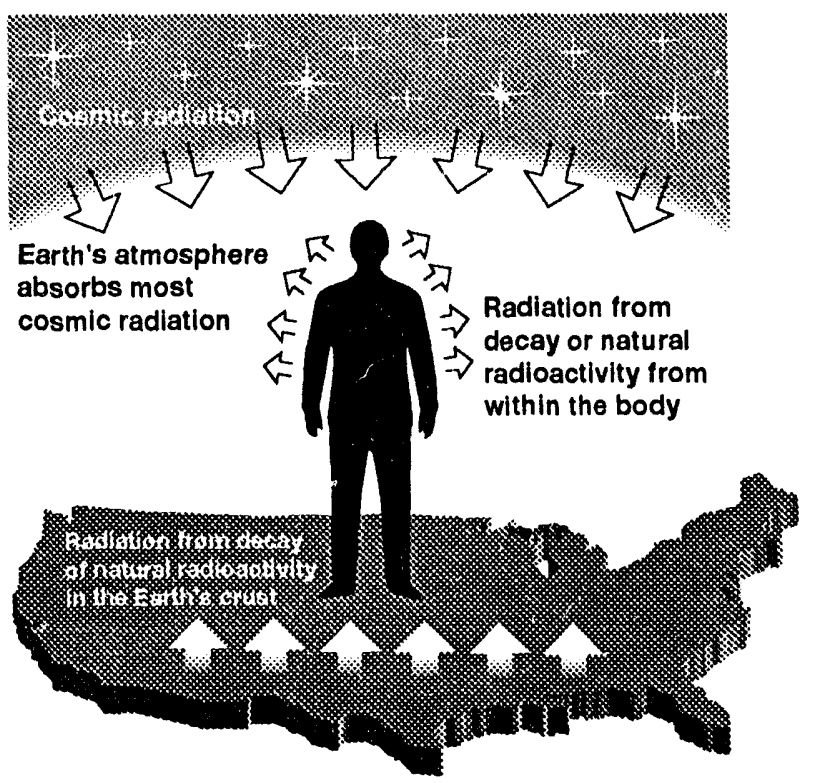

$93 \times 1665.01$. AlL

\section{Figure 3 Natural Radiation}

Even though people cannot feel, taste, smell, see, or hear radiation, it is everywhere, and natural sources of radiation simply overwhelm all man-made sources. 


\section{Man-made Radiation}

In addition to natural radiation, there are man-made sources of radiation (figure 4). Examples include consumer products, medical sources, and fallout from atmospheric atomic bomb tests.

Consumer Products Some consumer products are sources of radiation. In some of these products, like smoke detectors and airport X-ray baggage inspection systems, the radiation is essential to the performance of the device. In other products, such as televisions and tobacco products, the radiation occurs incidentally to the product function.

Medical Sources This is the main source of man-made radiation. Exposure is deliberate and directly beneficial to the patients exposed. In general, medical exposures from X-rays result from beams directed to specific areas of the body. Nuclear medicine examinations and treatment involve the internal administration of radioactive compounds by injection, inhalation, consumption, or insertion. Radiation and radioactive materials are also used in a wide variety of pharmaceuticals and in the preparation of medical instruments, including the sterilization of heatsensitive products such as plastic heart valves.

Other Sources Other sources of radiation include fallout from atmospheric atomic bomb tests; emissions of radioactive materials from nuclear facilities, such as uranium mines, fuel processing plants, and nuclear power plants; emissions from mineral extraction facilities; and transportation of radioactive materials.

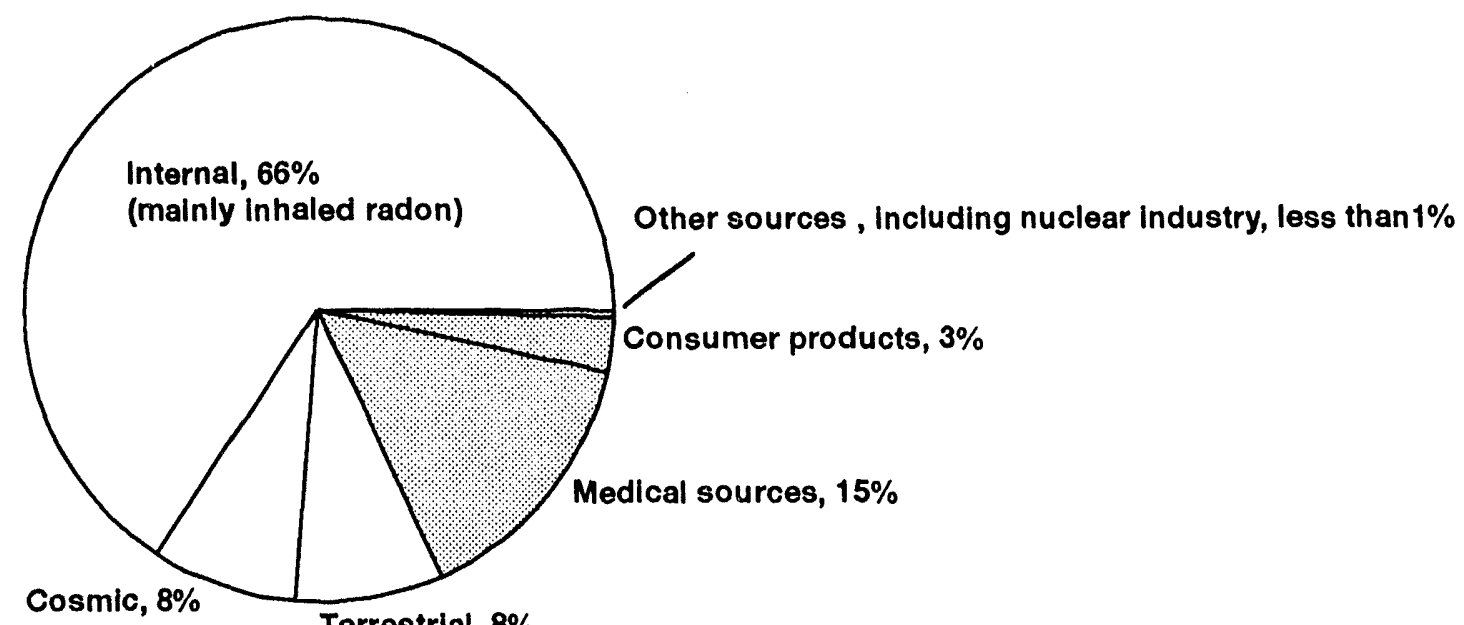

Figure 4 Natural and Man-made Radiation

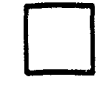

Natural

Man-made
Most of the radiation people are exposed to occurs naturally. It has always been present, and every person who has ever lived has been exposed. While modern technology may seem to have greatly increased the exposure rate, this is not necessarily the case; however, exposure to man-made radiation varies greatly based on individual product choices and medical treatments. 


\section{Comparison of Dose Levels}

The dose received by a given individual can vary greatly from year to year depending on numero!s factors, such as medical treatments. The average individual in the United States receives a dose more than 200 times greater from natural, internal exposure than from nuclear industry operations (table 1).

Table 1 Average Annual Dose in the United States

(Reference 2)

\begin{tabular}{lrlrr}
\hline Radia*ion Type & Average Dose & & Radiation Type & Average Dose \\
\cline { 5 - 5 } \cline { 5 - 5 } Natural & & & Man-made & \\
Cosmic & $27 \mathrm{mrem}$ & & Consumer Products & $13 \mathrm{mrem}$ \\
Terrestrial & $28 \mathrm{mrem}$ & & Medical Sources & $53 \mathrm{mrem}$ \\
Internal & $239 \mathrm{mrem}$ & & Other & $<1 \mathrm{mrem}$ \\
(mainly inhaled radon) & & & (includes nuclear industry) & \\
\hline
\end{tabular}

The average dose caused by natural radiation also varies widely. In the United States, the average is about 300 mrem per year; however, some people in other parts of the world receive a dose more than four times this amount. For example, in some areas of Brazil, inhabitants' dose can be more than 2,000 mrem per year from natural radiation. These wide variations are due to several factors, most notably the type and amount of radionuclides in the soil (figure 5).

This diversity in natural radiation, not man-made radiation, is responsible for the large differences in the dose of most individuals. This is important to keep in mind because levels of natural radiation are the standards of comparison for man-made radiation. The magnitude and variability of natural radiation have been suggested as the basis for setting limits on exposure to man-made radiation (table 2 ).

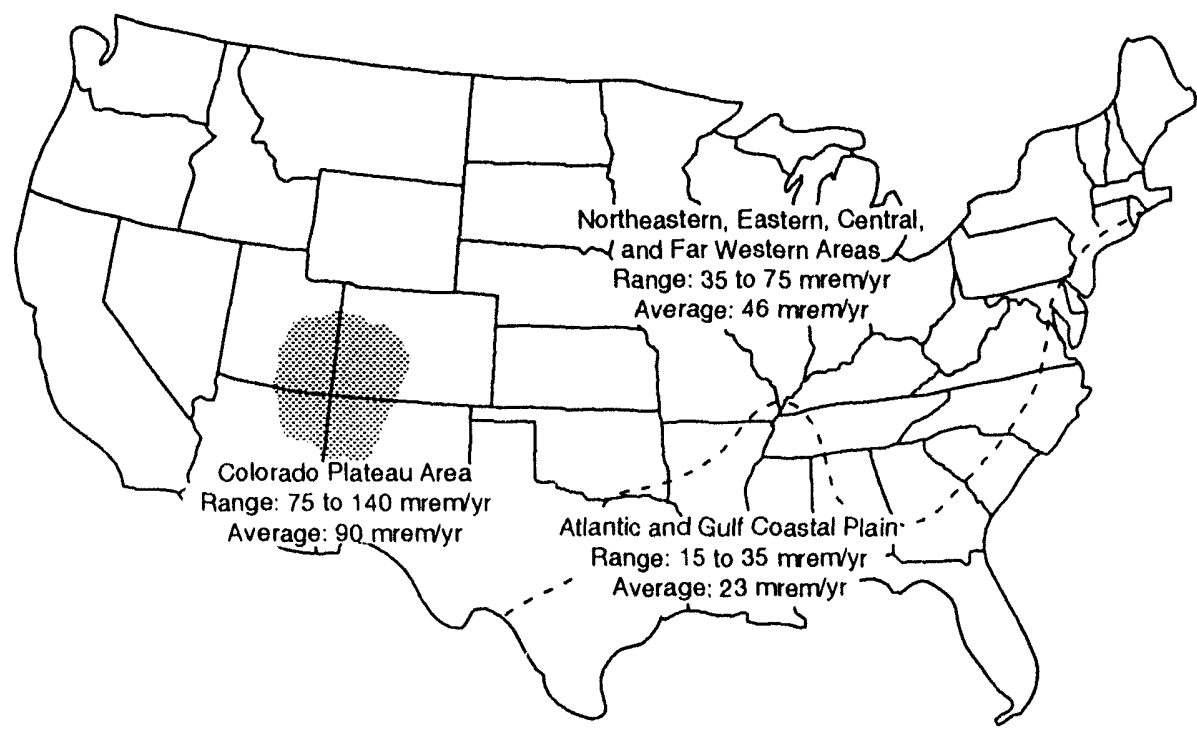

Figure 5 Average Dose from Terrestrial Radiation in the United States

Large deposits of uranium and thorium ores in the Southwest are responsible for the higher-than-average dose in the area known as the Colorado Plateau. 


\section{Table 2 Comparison and Description of Various Dose Levels}

\section{Dose Description}

1 mrem Approximate daily dose from natural radiation, including that due to radon (Reference 2).

2.5 mrem Cosmic dose to a person on a one-way airplane flight from New York to Los Angeles (Reference 2).

8 mrem Typical duse from one chest $X$-ray using modern equipment (Reference 4).

10 mrem Annual exposure limit, set by U.S. Environmental Protection Agency, for exposures from airborne emissions from operations of nuclear fuel cycle facilities, including power plants, uranium mines, and mills (Reference 5).

46 mrem Estimate of the largest dose any off-site person could have received from the March 28, 1979, Three Mile Island nuclear accident (Reierence 6).

66 mrem

Average yearly dose to people in the United States from man-made sources (Reference 2).

100 mrem Annual limit of dose from all U.S. Department of Energy facilities to a member of the public who is not a radiation worker (Reference 5 ).

110 mrem Average occupational dose received by U.S. commercial radiation workers in 1980 (Reference 7).

170 mrem Average yearly dose to an airline flight crew member from cosmic radiation and transport of radioactive materials by air (Reference 7).

244 mrem Average dose from a upper gastrointestinal diagnostic X-ray series (Reference 4).

$300 \mathrm{mrem}$ Average yearly dose to people in the United States from all sources of natural radiation (Reference 2).

1-5 rem U.S. Environmental Protection Agency's Protective Action Guidelines state that public officials should take emergency action when the dose to a member of the public from a nuclear accident will likely reach this range (Reference 8 ).

5 rem Annual limit for occupational exposure of radiation workers set by the U.S. Nuclear Regulatory Commission and the U.S. Department of Energy (References 9 and 10).

10 rem The BEIR V report estimated that an acute dose at this level would result in a lifetime excess risk of death from cancer, caused by the radiation, of 0.8 percent (Reference 11 ).

25 rem U.S. Environmental Protection Agency's guideline for voluntary maximum dose to emergency workers for non-lifesaving work during an emergency (Reference 8).

75 rem U.S. Environmental Protection Agency's guideline for maximum dose to emergency workers volunteering for lifesavirig work (Reference 8 ).

50-600 rem Doses in this range received over a short period of time will produce radiation sickness in varying degrees. At the lower end of this range, people are expected to recover completely, given proper medical attention. At the top of this range, most people will die within 60 days (Reference 12). 


\section{The Savannah River Site}

SRS is one of several government-owned, contractor-operated sites in the U.S. Department of Energy (DOE) nuclear defense complex. The Westinghouse Savannah River Company (WSRC) has operated the site since April 1, 1989.

SRS was constructed during the early 1950 s to produce basic raterials used in the fabrication of nuclear weapons. While SRS still handles nuclear materials for government use and some civilian purposes, the major focus has shifted to environm ental restoration and waste management.

SRS is located along the Savannah River, principally in Aiken and Barnwell counties of South Carolina (figure 6). The site is approximately 25 miles southeast of Augusta, Georgia, and 12 miles south of Aiken, South Carolina. Farming in the region is diverse and includes crops, such as cotton, soybeans, corn, and small grains. Area industrial and manufacturing facilities include textile mills, plants that produce polystyrene foam and paper products, chemical processing plants, and a commercial nuclear power plant.

The Savannah River flows along the southwestern border of SRS for approximately 17 miles, with five major streams from SRS feeding it. These streams, which receive discharges from various SRS operations, are not used as commercial or domestic sources of water. The Savannah River is used as a drinking water supply for approximately 65,000 people about 100 miles downriver in Port Wentworth, Georgia, and in Beaufort and Jasper counties of South Carolina. There is no known use of the Savannah River for irrigation by farming operations downstream of SRS.

\section{SRS Initial Construction Facts}

In less than five years, initial construction-consisting of five reactors, two chemical separations facilities, a heavy water extraction plant, a nuclear fuel and target fabrication facility, and waste management facilities-was complete. By the time the basic site was finished in 1956, the project had used a third of the country's concrete supply and half of its stainless steel supply. The total cost was $\$ 1.1$ billion, including the cost for the land.

Earth moved: $39,150,000$ cubic yards $=$ a wall 10 feet high and 6 feet wide from Atlanta, Georgia, to Portland, Oregon

Concrete: $1,453,000$ cubic yards $=$ a highway 6 inches thick and 20 feet wide from Atlanta, Georgia, to Philadelphia, Pennsylvania

Reinforcing steel: 118,999 tons $=3,300$ cars or a train 30 miles long

Structural steel: 27,000 tons $=$ a train 18 miles long

Lumber: $85,000,000$ board feet $=$ enough lumber for a city of 15,000 homes with an average population of 45,000

Blueprints: $2,000,000$ blueprints $=$ a strip of paper 24 inches wide reaching from Atlanta, Georgia, to Seattle, Washington 


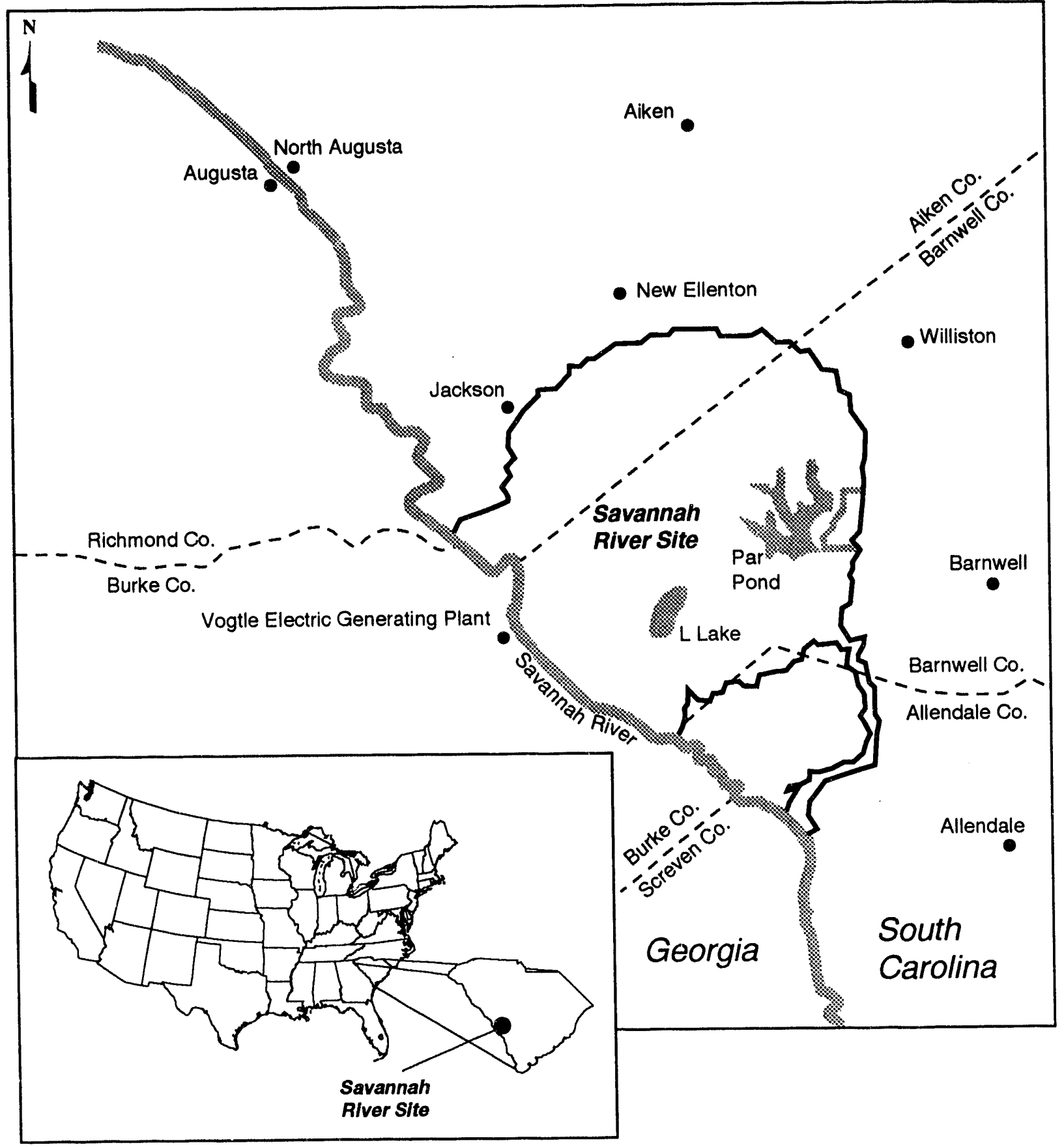

M93A022.01

Figure 6 Regional Location of SRS

SRS is about 25 miles southeast of Augusta, Georgia, and 12 miles south of Aiken, South Carolina. The site, approximately 310 square miles in area, covers about 1 percent of the state of South Carolina. 


\section{Effluent Monitoring and Environmental Surveillance}

Materials released to the environment during site operations are referred to as contaminants. They can, but do not always, contain radioactive elements. One of the goals of the environmental program at SRS is to identify and to quantify the releases resulting from site activities. While the basis for judging acceptable releases includes scientific studies as well as allowable levels set by federal and state regulatory agencies, the major concern is for the safety of site employees and the public in surrounding communities.

Effluent monitoring measures contaminants at the point of release. Environmental surveillance measures contaminants that have dispersed out into the environment. Contaminants released as a result of site operations can move through the environment to off-site locations, resulting in potential exposures to the public (figure 7). The term "pathway" is used to describe a potential route for contaminants to move through the environment. Pathways from airborne releases include inhalation, consumption of vegetation, and consumption of milk; pathways from liquid releases include consumption of fish, Savannah River water, and shellfish from the downriver estuary.

Contaminants can leave a facility in airborne or liquid discharges and end up in the food people eat or in the air they breathe. Monitoring measures contaminants as they are released; surveillance measures contaminants that have dispersed into the environment. 


\section{Regulators and Regulations}

Releases of nonradioactive and radioactive contaminants are regulated under many state and federal requirements, such as South Carolina Department of Health and Environmental Control (SCDHEC) permits, the federal Clean Air Act, the federal Clean Water Act, U.S. Environmental Protection Agency (EPA) standards, and DOE orders. Federal and state regulatory agencies set limits to ensure that releases are within safe levels. They also oversee SRS operations to provide an independent check on site activities and releases.

Nonradioactive Contaminants Regulations for nonradioactive contaminants set limits for how much of a substance a facility may release. The limits stress that releases should be minimized consistent with available technology. There are separate regulations for releases to surface water and to air.

Releases to surface water are regulated by SCDHEC under the National Pollutant Discharge Elimination System (NPDES) program. The NPDES program was created by the federal Clean Water Act of 1972 . Monitoring requirements vary from one release point to another depending on the types of materials potentially present and the known characteristics of the wastewater. Releases to air are regulated under the federal Clean Air Act and state statutes through permits issued by SCDHEC.

Radioactive Contaminants Among the regulations that control radiological operations are DOE Order 5400.1, "General Environmental Protection Program"; DOE Order 5400.5, "Radiation Protection of the Public and the Environment"; National Emission Standards for Hazardous Air Pollutants; and DOE/ EH-0173T, Environmental Regulatory Guide for Radiological Effluent Monitoring and Environmental Surveillance. Some regulations for radioactive contaminants set a limit on the amount of radioactivity released; however, some set a limit on the dose a person could receive from these releases. A discussion of these limits and the dose estimates from SRS operations for 1993 begins on the next page.

\section{Quality Assurance and Quality Control}

When monitoring releases and measuring radiation in the environment, there must be confidence that the data are reliable. To ensure that the monitoring and measurement results are accurate, SRS has a quality assurance and quality control program based on state and federal guidelines as well as WSRC quality control requirements. SCDHEC also conducts monthly inspections and collects samples at discharge points for comparison with SRS sampling results. Subcontractor laboratories that provide services for SRS must have established quality assurance and quality control programs and must participate in interlaboratory comparisons, evaluations, and audits of their facilities. These laboratories must also be certified by the State of South Carolina. 


\section{Radiological Monitoring and Surveillance}

Each year thousands of samples are collected and analyzed for radioactive contaminants. Samples are collected from on-site locations, along the site boundary, and at off-site locations up to 100 miles away. In 1993, approximately 105,000 radiological analyses were performed on 27,000 samples.

Before discussing the results of the radiological monitoring program, it is important to understand the terminology used in measuring radiation and radioactivity.

\section{Measuring Radiation}

To determine the possible effects of radiation on the health of the environment and people, it must be measured. More precisely, the radiation's potential to cause damage must be ascertained.

Activity When measuring the amount of radiation in the environment, what is actually being measured is the rate of radioactive decay, or radioactivity, of a given element. This radioactivity is expressed in a unit of measure known as a curie $(\mathrm{Ci})$. A curie is a measure of radioactivity, not a quantity of material. More specifically, one curie equals 37 billion atom disintegrations per second. One gram of a radioactive substance may contain the same amount of radioactivity as several tons of another radioactive substance. For example, one gram of tritium equals about $10,000 \mathrm{Ci}$, while one gram of uranium equals about $0.000000333 \mathrm{Ci}$.

Dose The measure of potential biological damage caused by radiation is expressed in a unit of measure known as a rem. One rem of any type of radiation has the same total damaging effect, regardless of the source of the radiation. Since most people receive doses below $1 \mathrm{rem}$, dose is usually expressed as a millirem (mrem), or 1/1,u00 of a rem.

\section{Calculating Dose}

With modern technology, very small amounts of radionuclides in environmental samples can be detected. However, many of the radionuclides released from SRS have such low concentrations when dispersed into the environment that they cannot be measured using laboratory methods. Also, it can be impossible to tell if a radionuclide in the environment comes from SRS or from another source, such as fallout from nuclear weapons testing. These factors make it difficult to measure directly the public's exposure to some of the radioactive materials released from the site. Therefore, mathematical models must be used to estimate the concentrations of radionuclides present in the environment as a result of the measured releases to air and water.

Basically, all air and liquid discharges from SRS are monitored. Beginning with these measurements and factoring in many other conditions (e.g., wind direction, river flow rates, and, in some cases, actual measurements from environmental samples), concentrations are calculated. These concentrations are used to compute estimated doses from site releases. 
When calculating maximum doses from releases to the air and water from SRS operations, the concept of a hypothetical individual who receives the maximum exposure from all pathways is used.

- For air pathways: The maximally exposed individual lives at the SRS boundary 365 days a year and consumes milk, meat, and vegetables produced at that location.

- For liquid pathways: The maximally exposed individual lives downriver from SRS 365 days a year, drinks one liter of untreated water directly from the Savannah River each day, eats a large amount of fish from the river, and spends the majority of time on the river.

SRS uses the concept of the maximally exposed individual when estimating its contribution to the dose of the off-site population to ensure that the estimate is the highest any one individual could have received as a result of site operations. However, no such individual is known to exist. It is also important to remember that the estimated dose reported by SRS is the SRS contribution to an individual's dose; everyone is exposed to radiation and receives a dose from that radiation regardless of SRS operations.

\section{Uncertainty in Dose Calculations}

The reported SRS contribution to dose is a calculated estimate. And, as with every estimate, there is a level of uncertainty. With dose calculations, many different physical parameters must be considered.

To calculate estimated doses to the off-site public, SRS uses standard, U.S. Nuclear Regulatory Commission-approved radiation transport and dose models developed for the commercial nuclear industry. These computer-based models are regularly tested and verified to ensure that they provide proper and conservative (i.e., reasonable upper bound) estimates. They are also routinely updated to keep the uncertainty of the dose estimates as low as possible when site-specific conditions, such as weather patterns or river flow, change.

But keep in mind that there is simply no way to verify exactly how much radioactivity was in the air, on vegetation, or in the water at any given place and time. Aiso, individual dose depends in large part on personal choices, such as diet, time spent indoors versus outdoors, and how much time a person spent in this area versus time away on vacation. It is impossible to determine any one individual's exact dose from SRS or from any other source. The maximally exposed individual concept provides an upper bound estimate for the SRS contribution to that dose by assuming worst-case conditions resulting from personal choices. 
Table 3 lists the maximum doses that could have been received by the public from SRS operations in 1993. Doses are calculated for maximally exposed individuals. Figure 8 gives a brief overview of dose trends over the past 10 years.

\section{Federal Radiation Protection Standards}

Federal authorities have set limits on the amount of radiation the public can receive from facilities such as SRS. These regulations state that the dose to an individual shall not exceed 10 mrem per year from releases of radioactivity to the air, or 4 mrem per year from releases of radioactivity to treated drinking water. The maximum limit for all types of exposures to the public from a DOE facility is 100 mrem per year. There is no separate limit from liquid releases alone, but these releases are included in the $100 \mathrm{mrem}$ for total releases.

\section{Largest Dose Contributors for 1993}

While many different radionuclides are released during SRS operations, fewer than ten were significant contributors to the potential dose to people near the site. The two most important radionuclides in terms of their contribution to dose were tritium and cesium-137. In 1993, these two radionuclides accounted for approximately 90 percent of the dose to the maximally exposed individual from SRS releases.

Tritium releases to surface water accounted for more than 40 percent of the total liquid pathways dose. Cesium-137 in fish was the largest contributor (more than 50 percent) to the total dose from liquid pathways. Tritium was the largest contributor to doses from the airborne pathway and from treated drinking water.

The maximum dose in 1993 from eating Savannah River fish caught near the site was estimated to be $0.08 \mathrm{mrem}$. This dose is based on measured rather than calculated concentrations. Some fraction of the cesium-137 measured in fish is due to

\section{Dose (mrem)}

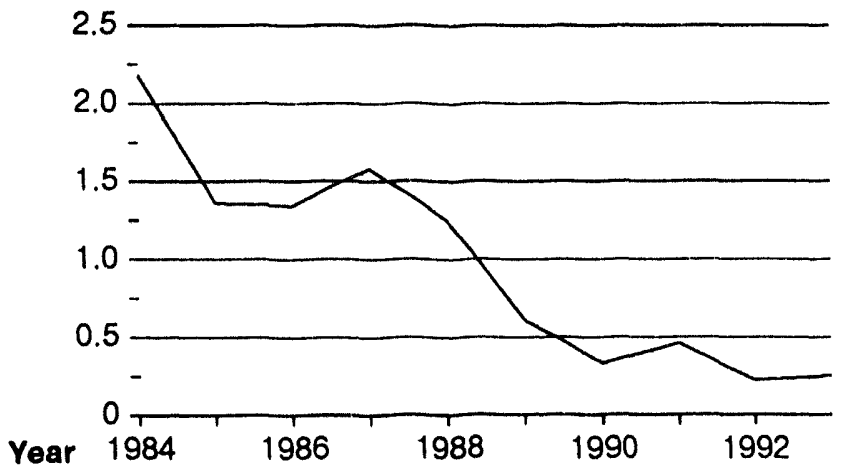

Figure 8 Dose from 1984 to 1993

As production facilities have shut down and as the site mission has changed from manufacture to restoration, there has been a decrease in site releases and the resulting dose. 
worldwide fallout. However, that fraction is difficult to determine and is not subtracted from the total used to estimate the dose. Therefore, the calculated dose from consumption of cesium-137 in fish overestimates the contribution from SRS releases.

As a result of site releases, increased levels of tritium are present in the drinking water downriver from the site. Samples of the drinking water from two treatment plants (the Beaufort-Jasper Water Treatment Plan near Beaufort, S.C., and the Cherokee Hill Water Treatment Plant at Port Wentworth, Ga.), located approxi-

Table 3 Comparison of Calculated Dose Estimates for Maximally Exposed Individuals for 1993 from SRS Releases with Applicable Standards and Natural Radiation

\begin{tabular}{|c|c|c|c|c|c|}
\hline \multicolumn{2}{|c|}{$\begin{array}{l}\text { Exposure } \\
\text { Pathway }\end{array}$} & $\begin{array}{l}\text { Maximum Dose } \\
\text { m SRS Releasesa }\end{array}$ & $\begin{array}{l}\text { Applloable } \\
\text { Standardb }\end{array}$ & $\begin{array}{c}\% \text { of } \\
\text { Standard }\end{array}$ & $\%$ of Natural ${ }^{\circ}$ \\
\hline \multicolumn{6}{|c|}{ Alrbome releases } \\
\hline \multicolumn{2}{|c|}{ Inhalation } & 0.05 mrem & & & \\
\hline \multicolumn{2}{|c|}{ Other } & 0.06 mrem & & & \\
\hline \multicolumn{2}{|c|}{ Total airborne } & 0.11 mrem & 10 mrem $^{d}$ & 1.10 & 0.04 \\
\hline \multicolumn{6}{|c|}{ Liquid releases } \\
\hline \multicolumn{2}{|c|}{ Fish consumption } & $0.08 \mathrm{mrem}$ & & & \\
\hline \multicolumn{2}{|c|}{ Other } & 0.06 mrem & & & \\
\hline \multicolumn{2}{|c|}{ Total llquid } & 0.14 mrem & $N / A^{\theta}$ & $N / A^{\theta}$ & 0.05 \\
\hline \multicolumn{2}{|c|}{ All pathways' } & 0.25 mrem & 100 mrem & 0.25 & 0.08 \\
\hline \multicolumn{6}{|c|}{ Treated drinking water } \\
\hline \multicolumn{2}{|c|}{ Beaufort-Jasper } & 0.04 mrem & 4 mrem $^{g}$ & 1.00 & 0.01 \\
\hline \multicolumn{2}{|c|}{ Port Wentworth } & 0.05 mrem & 4 mrem $^{9}$ & 1.25 & 0.02 \\
\hline \multicolumn{6}{|c|}{ Sportsman } \\
\hline & On-site hunter & 57.30 mrem & 100 mrem & 57.30 & 19.10 \\
\hline & Off-site individual & 4.05 mrem & 100 mrem & 4.05 & 1.35 \\
\hline & consumption & 1.30 mrem & 100 mrem & 1.30 & 0.43 \\
\hline $\bar{a}$ & \multicolumn{5}{|c|}{ Effective dose equivalent (EDE). } \\
\hline$b$ & \multicolumn{5}{|c|}{ All the limits listed are given in DOE Order 5400.5, Feb. 8, 1990, "Radiation Protection of the Public and the Environment." } \\
\hline c & \multicolumn{5}{|c|}{ Estimate of average EDE received from natural radiation is 300 mrem per year (Reference 13). } \\
\hline d & \multicolumn{5}{|c|}{$\begin{array}{l}\text { The standard for airborne effluents applies to the sum of the doses from all airborne pathways: inhalation, submersion in a } \\
\text { plume, exposure to radionuclides deposited on the ground surface, and consumption of foods contaminated as a result of the } \\
\text { deposition of radionuclides. }\end{array}$} \\
\hline e & \multicolumn{5}{|c|}{$\begin{array}{l}\text { There is no separate standard for all liquid pathways alone; all liquid releases are included in the } 100 \text { mrem standard for all } \\
\text { pathways. }\end{array}$} \\
\hline 1 & \multicolumn{5}{|c|}{$\begin{array}{l}\text { The total airborne and liquid exposure pathways are added in order to compare maximum calculated doses from SRS re- } \\
\text { leases with the DOE "all pathways" standard. This total includes the maximum airborne EDE of } 0.11 \text { mrem and the maximum } \\
\text { liquid EDE of } 0.14 \text { mrem. }\end{array}$} \\
\hline g & \multicolumn{5}{|c|}{$\begin{array}{l}\text { The drinking water standard applies to public commurity drinking water systems and drinking water supplies operated by } \\
\text { DOE or DOE contractors. }\end{array}$} \\
\hline
\end{tabular}


mately 100 miles downriver, are collected daily by treatment plant personnel. The daily samples from each facility are composited each month for analysis by SRS.

\section{Sportsman Doses}

Nontypical exposure pathways, not included in the 100 mrem per year standard maximally exposed individual dose calculations, are considered separately from the maximally exposed individual doses. This is because they apply to relatively low-probability (such as consumption of fish caught exclusively from the mouths of SRS streams) or unique (such as volunteer deer hunters) scenarios.

Deer and Hog Consumption Pathway Originally, only a handful of white-tail deer could be found on site. Now, they number more than 5,000. Because of this large population, deers hunts are held each year to control the population. Such control of the herd is important to the herd's health and helps reduce the number of deercar accidents.

Feral hogs on site, once domesticated, are completely wild and tend to destroy valuable plant communities, timber, and ecological research sites. There are more than 2,000 hogs on site. They are harvested during the deer hunts to control the population and to reduce the damage done by the animals.

In 1993,14 hunts were held from October and to December. During the hunts, 1,553 deer and 147 hogs were taken from the site. Every animal killed during a hunt is monitored in the field for cesium-137. If the field measurement shows that a hunter would receive a dose of greater than 99 mrem (based on the $100 \mathrm{mrem}$ limit for all pathways), the hunter is not allowed to remove the animal from the site. In addition, samples of flesh and bone from every 10 th animal are taken to the laboratory for more precise measurements.

The maximum dose to a hunter in 1993 was estimated to be 57 mrem. This individual harvested seven animals. The estimated dose assumes the hunter alone consumed the entire edible portion of all seven animals (about 360 pounds).

Another deer meat consumption pathway considered was for a hypothetical individual whose entire intake of meat during the year was deer meat. It was assumed that this hypothetical individual harvested deer that had resided on SRS, but then moved off site. The estimated dose was based on the average cesium-137 concentration measured in deer during the 1993 hunts and the maximum meat consumption rate for an adult of 180 pounds of meat per year. The potential maximum dose from this pathway was estimated to be $4.1 \mathrm{mrem}$.

Fish Consumption Pathway The maximum dose from this pathway was estimated to be 1.3 mrem from the consumption of bass collected at the mouth of Steel Creek. This hypothetical dose is based on the scenario that during 1993, a fisherman consumed 42 pounds of bass caught exclusively from the mouth of Steel Creek. Some fraction of this estimated dose is due to cesium-137 present from worldwide fallout; however, that amount is difficult to determine and is not subtracted from the total. 


\section{Radiation Assessment Program}

In 1988, preparation of documents describing the effects of SRS operations on the environment began. Plans are to prepare separate documents for each of the major radionuclides. The documents describe the operating history of the site with regard to the production, storage, and release of each radionuclide. The transport of the radionuclide in air, surface water, and groundwater is explained, and a calculation of the dose estimate is presented (table 4). As of December 31, 1993, several documents had been published ${ }^{a}$ :

Tritium in the Savannah River Site Environment, WSRC-RP-90-424-1, Rev. 1

Cesium in the Savannah River Site Environment, WSRC-RP-92-250

Uranium in the Savannah River Site Environment, WSRC-RP-92-315

Radioiodine in the Savannah River Site Environment, WSRC-RP-90-424-2

Assessment of Radiocarbon in the Savannah River Site Environment, WSRCTR $-93-215$

Assessment of Technetium in the Savannah River Site Environment, WSRCTR-93-217

Plutonium in the Savannah River Site Environment, WSRC-RP-92-879, Rev. 1

A document has been prepared for strontium, and the tritium document has been updated. Publication of these reports is scheduled for early 1994. Documents for noble gases and mercury are in production and are scheduled for publication early in 1995.

Table 4 History of Radiation Dose from SRS Releases

\begin{tabular}{|c|c|c|c|}
\hline \multirow[t]{2}{*}{ Radlonuclide } & \multicolumn{2}{|c|}{$\begin{array}{l}\text { Maximally Exposed Individual Dose } \\
\text { (mrem) }\end{array}$} & \multirow{9}{*}{$\begin{array}{l}\text { Since site startup, releases have been } \\
\text { monitored and the resulting doses calcu- } \\
\text { lated. The dose contributed to the maxi- } \\
\text { mally exposed individual by SRS releases } \\
\text { over a } 38 \text {-year period ( } 1954 \text { to } 1992 \text { ) is } \\
\text { less than } 1 \text { percent of the } 13,000 \text { mrem } \\
\text { dose an individual would have received } \\
\text { from radiation from natural and medical } \\
\text { sources. }\end{array}$} \\
\hline & Alrborne & Llquild & \\
\hline Tritium & 25 & 7 & \\
\hline Cesium & 0.3 & 60 & \\
\hline Uranium & 0.5 & 0.6 & \\
\hline lodine & 32 & 1 & \\
\hline Carbon & 1.1 & 0 & \\
\hline Technetium & 0.1 & 0.008 & \\
\hline Total & 59 & $\Rightarrow 69$ & \\
\hline
\end{tabular}

a Coples of these documents can be obtained from the National Technical Information Service, U.S. Department of Commerce, 5285 Port Royal Road, Springfield, VA 22161 
Releases to the environment from SRS depend largely on which facilities operate and what maintenance activities occur during the year. However, groundwater migration from seepage basins is also important when determining liquid releases. The term "releases" includes any radionuclide that has moved off site.

Tritium was the major contributor to air and liquid releases. In fact, tritium accounted for more than 99 percent of the total radioactivity released in 1993. Remember that these numbers are for the amount of radioactivity released, not the potential dose caused by the radiation.

\section{Airborne Releases}

In $1993, \mathrm{SRS}$ released $191,000 \mathrm{Ci}$ of tritium to the air (mainly from reactors and tritium facilities) as compared to $156,000 \mathrm{Ci}$ in 1992 . This 22-percent increase is attributed to increased operations in the tritium facilities.

\section{Liquid Releases}

In 1993, liquid releases included $11,300 \mathrm{Ci}$ of tritium (mainly from seepage basins, reactors, and the Effluent Treatment Facility) as compared to $13,800 \mathrm{Ci}$ in 1992. The large decrease in liquid releases is directly attributable to the shutdown of all reactor facilities. Approximately 87 percent of the liquid releases were a result of seepage basin migration (figure 13, page 22). Direct discharges of process effluents resulted primarily from operations in the reactors and separations areas.

The measured direct release of cesium-137 to the Savannah River in 1993 was $0.246 \mathrm{Ci}$, primarily from operations in the separations areas.

\section{Past Releases}

Releases of tritium to air and to the Savannah River from SRS operations from 1987 to 1993 are shown in figures 9 and 10 . Tritium releases to the air have decreased steadily over the last several years as a result of no reactors operating.

Measured cesium-137 releases to the Savannah River from 1987 to 1993 are shown in figure 11. Operations in the separations areas are the major source of releases to the Savannah River. 
Quantity Releseed (Curles)

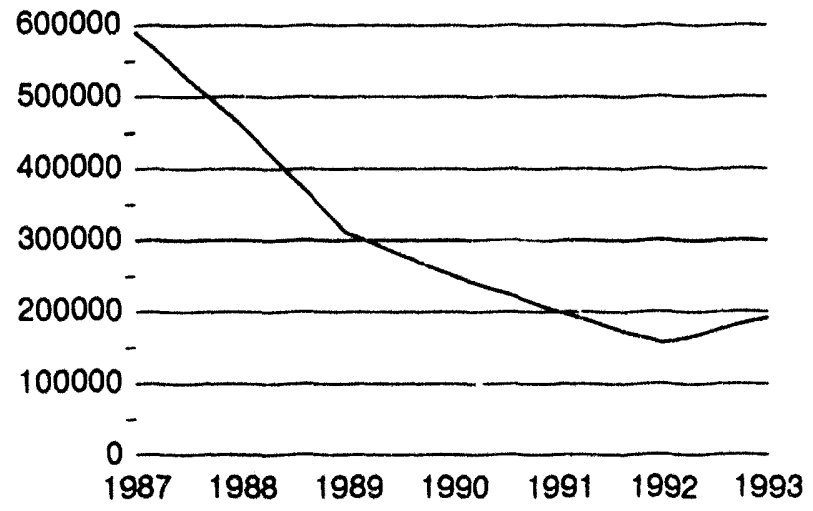

Quantity Released (Curles)

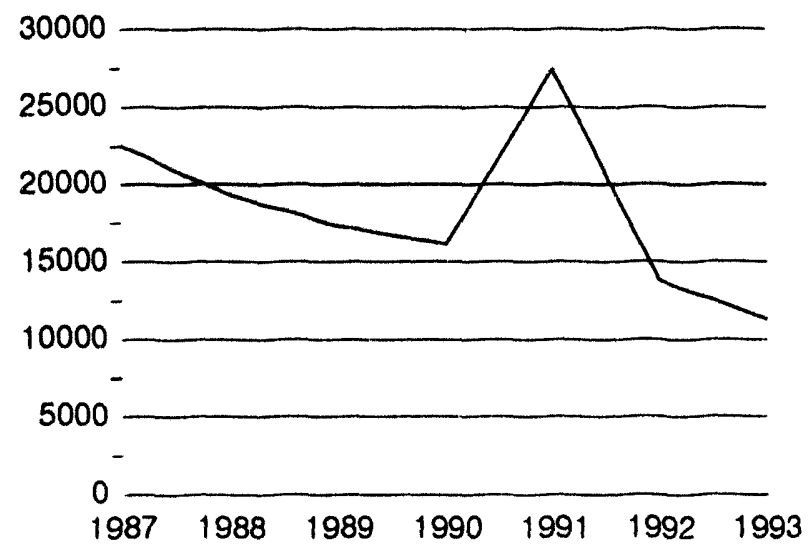

Quantity Released (Curies)

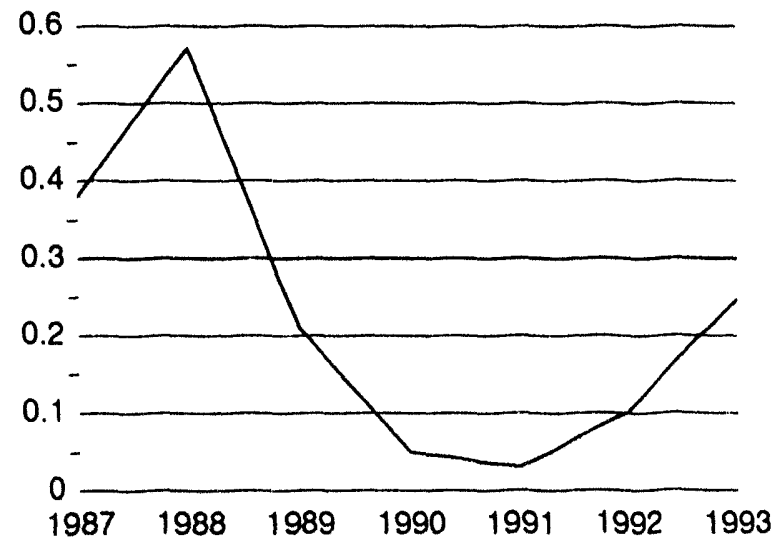

Figure 9 Tritium Releases to the Air

lleaf Graphic

Figure 10 Tritium Releases to the Savannah River

lleaf Graphic

Figure 11 Cesium-137 Releases to the Savannah River

lleaf Graphic 


\section{Nonradiological Monitoring and Surveillance}

The nonradiological program is designed to ensure that airborne and liquid releases are safe and within regulatory limits. Based on established guides, the program focuses on monitoring of airborne and liquid releases and surveillance of the environment, including surface water (site streams and the Savannah River), drinking water, sediment, fish, and groundwater. In 1993, more than 20,000 analyses for specific chemicals and metals were performed on over 7,000 samples, not including groundwater. The single largest nonradiological effort was directed toward groundwater. Approximately 600,000 nonradiological analyses were performed on groundwater samples collected from more than 1,600 monitoring wells. A summary of the 1993 results follows.

\section{Alrborne and Liquid Releases}

All calculated emissions were within applicable SCDHEC standards during 1993. However, two H-Area boilers exceeded their permit limit for particulate emissions. SRS received a Notice of Violation for these exceedances. The issue had not been resolved as of December 31,1993, but a settlement agreement is expected to be finalized in 1994 .

For liquid releases, SRS has maintained an NPDES compliance rating above 99 percent since 1986 (figure 12). Of the 8,000 analyses performed in 1993, only ten exceeded permit limits. The ten exceedances occurred at eight different release points.

\section{Surface Water (Streams and the Savannah River)}

Until April 23, 1992, the South Carolina Water Quality Standards for Class B waters defined the chemical and biological standards for site streams and the Savannah River. On April 24, 1992, the State of South Carolina imposed new, more stringent regulations on the waters of the state. At that time, the classification of site streams and the Savannah River was changed from Class B waters to Freshwaters. With this change in standards, 76 fecal coliform excursions occurred in 1993.

\section{Drinking Water}

The 27 on-site drinking water systems are monitored by SRS personnel. Samples are analyzed for total coliform bacteria. Samples for chemical and volatile organics analyses are collected annually from the 13 larger systems and biannually for the smaller ones. In 1993, the 13 larger systems were in compliance with SCDHEC standards for total coliform bacteria. All samples collected by SCDHEC for volatile organics met state standards.

Of the 1,470 sample results from the annual chemical analysis program, one exceeded SCDHEC primary (health-based) limits. All the larger systems met SCDHEC limits for lead and copper concentrations except for the Savannah River Forest Station system. Soda ash will be added to this system to adjust the $\mathrm{pH}$ and lower the levels of lead and copper. 


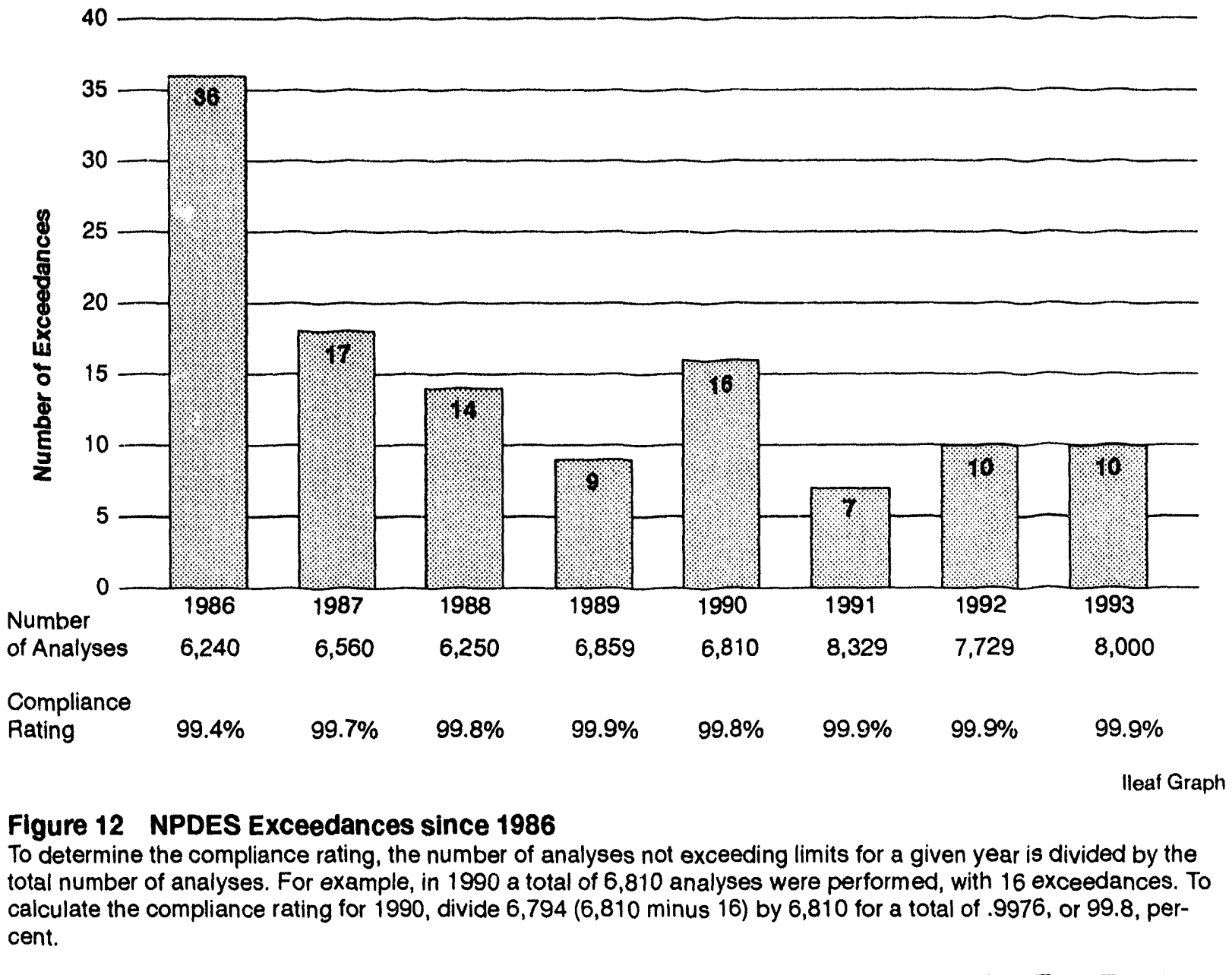

\section{Sediment}

Sediment from site streams and the Savannah River were analyzed for 22 herbicides in 1993. None were detected in any of the sediment samples. In 1993, a program designed to provide a surveillance method to determine if inorganic contaminants are being deposited in sediments in on-site streams was instituted. Because the program has been in existence for only one year and is designed to show trends, no conclusions can be drawn from the 1993 data.

Fish

In 1993, 211 fish from on site and off site were analyzed for mercury. SRS uses the U.S. Food and Drug Administr tion action limit of 1.0 micrograms of mercury per gram of fish flesh $(\mu \mathrm{g} \mathrm{Hg} / \mathrm{g})$ to gauge concentrations of mercury in fish.

Concentrations of mercury in on-site fish ranged from $2.87 \mu \mathrm{g} \mathrm{Hg} / \mathrm{g}$ to $0.03 \mu \mathrm{g} \mathrm{Hg} / \mathrm{g}$; concentrations in off-site fish ranged from $1.47 \mu \mathrm{g} \mathrm{Hg} / \mathrm{g}$ to $<0.01 \mu \mathrm{g} \mathrm{Hg} / \mathrm{g}$; concentrations in fish from the control location, the Edisto River, ranged from $0.3 \mu \mathrm{g} \mathrm{Hg} / \mathrm{g}$ to $0.1 \mu \mathrm{g} \mathrm{Hg} / \mathrm{g}$. 


\section{Groundwater}

An extensive groundwater monitoring program at SRS detects, characterizes, and tracks changes in groundwater contamination. The geology and climate at SRS make monitoring the groundwater important. The site is on the Coastal Plain, consisting sands and clays 200 to 300 meters deep. Much of the rain is absorbed by the sandy soils and moves through the ground toward streams and the Savannah River. The groundwater moves slowly, at rates ranging from a few inches to about 100 yards per year.

Scientists monitor the groundwater by collecting water from monitoring wells. The wells consist of PVC (polyvinyl chloride) or steel pipes cemented into a hole drilled into the groundwater. Each pipe has a section composed of small holes, or slots, called a screen zone. Water comes into the well through the screen zone. Commonly, several wells are placed near each other, with screen zones placed at different depths to monitor the groundwater in different aquifers.

Disposal of soluble solids and liquids at waste sites has caused groundwater contamination at SRS. Some liquids were placed in seepage basins that allowed them to seep into the ground (figure 13). Some solid materials and liquids were buried in landfills that allowed rainwater to seep through the waste and leach materials that then moved down to the groundwater. This groundwater is contaminated with radionuclides, metals, and organic chemicals. The nature of the contamination varies because operations at different parts of the site vary.

As shown in figure 14, large plumes of contaminated groundwater are near AArea and M-Area and in the center of SRS near the separations areas and the burial grounds. Much less extensive areas of groundwater contamination have been detected at numerous other sites. Scientists at the site have not detected any contaminated groundwater moving off the site, although contamination at A-Area, M-Area, and TNX has been detected near the site boundary.

Most of the contamination near A-Area and M-Area is caused by chlorinated volatile organic compounds used in the manufacturing operations in M-Area. These compounds are common contaminants of groundwater at many manufacturing facilities in the United States. In the central portions of SRS and near the reactors, tritium and other radionuclides are the most common groundwater contaminants.

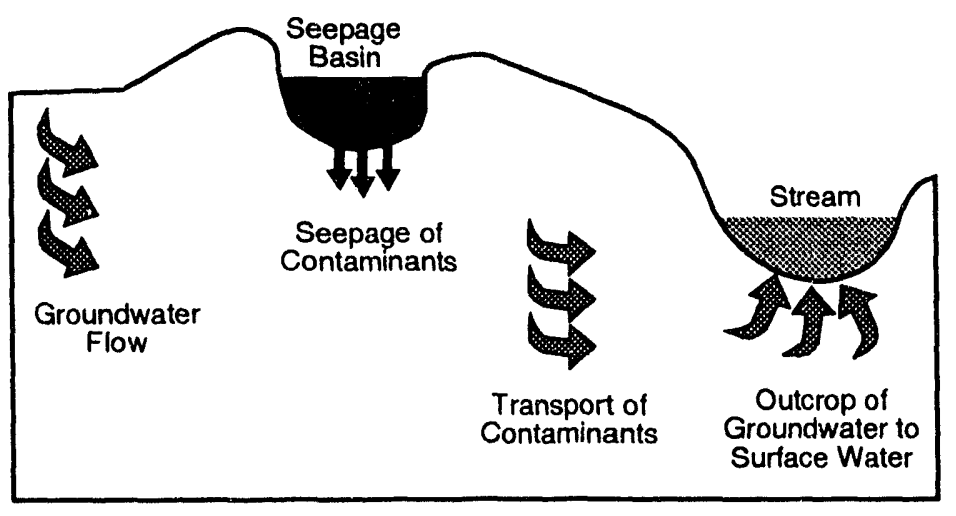

M9300592.02
Figure 13 Seepage Basin Migration

Seepage basins are shallow pits used to dispose of contaminated wastewater. Some of the wastewater evaporates; however, some of the wastewater and contaminants seep through the bottom of the basin into shallow groundwater. 
Figure 14 Groundwater Contamination at SRS

Groundwater beneath 5 to 10 percent of SRS has been contaminated by industrial solvents, metals, or other constituents used or generated by operations at the site. 


\section{Environmental Restoration and Waste Management}

Since the mid-1970s, several federal laws have been passed that more closely regulate the use and disposal of hazardous substances and require that contaminated areas be assessed and, if necessary, cleaned up. At SRS considerable effort has gone toward bringing all facilities and operations into compliance with appropriate regulations by initiating numerous restoration activities around the site.

DOE uses the term "environmental restoration" to refer to the assessment and, if necessary. cleanup of inactive sites (remediation) and facilities (decontamination and decommissioning). "Cleanup" means actions taken to deal with release or potential release of hazardous substances. This may mean complete removal of the substance; it also may mean stabilizing, containing or otherwise treating the substance so that it does not affect human health or the environment. Determining the most environmentally sound method of cleaning up each waste unit is a major component of the SRS environmental restoration program.

Six waste units totaling over 80 acres have been successfully closed under the Resource Conservation and Recovery Act (RCRA) permit at SRS. These closures are among the largest in the world and include the 58-acre Mixed Waste Management Facility Burial Ground containing mixed, hazardous, and radioactive waste (figure 15), as well as nine seepage and settling basins and a large restored Carolina bay.

SRS manages waste from generation through treatment, storage, and disposal. At the site waste has been generated as a result of the production of plutonium, tritium, and other nuclear materials. SRS manages transuranic waste, high-level radioactive waste, low-level radioactive waste, hazardous waste, mixed waste, and sanitary waste.

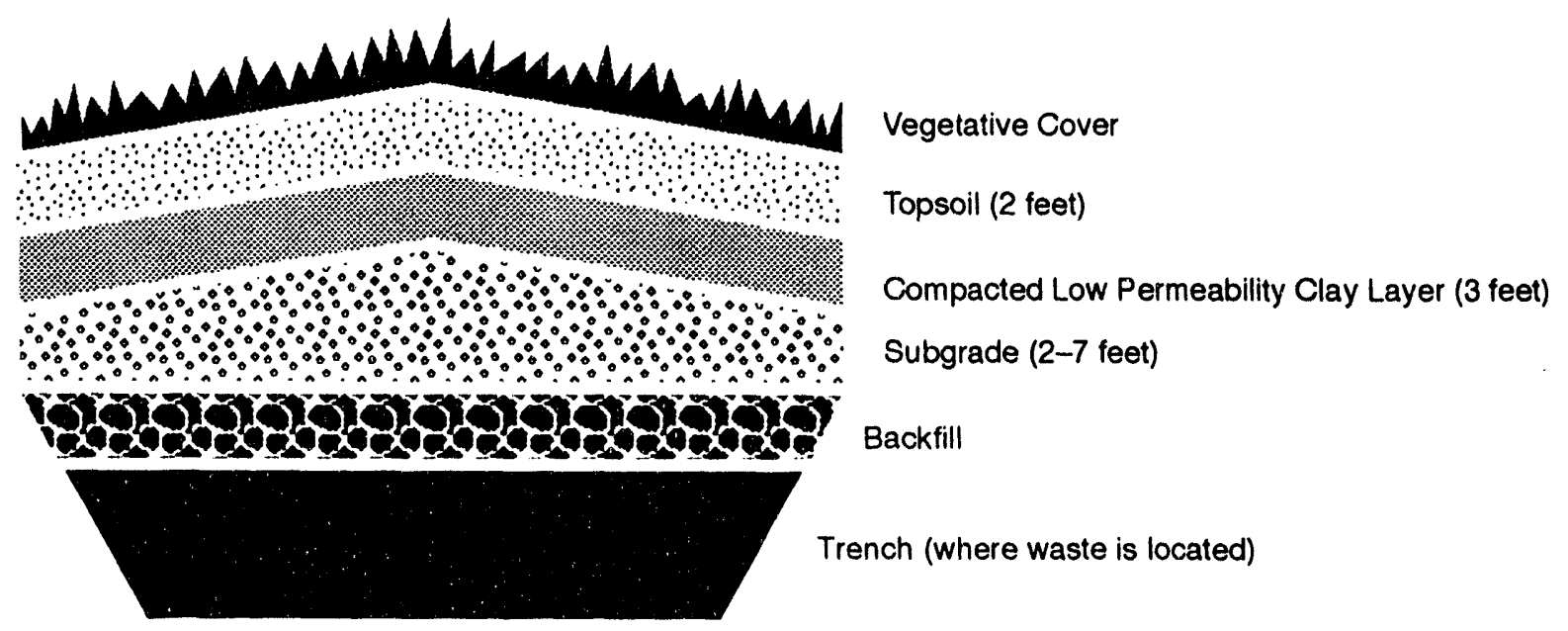

M93C034.01

Figure 15 Mixed Waste Management Facility Burial Ground Closure Cap Cross Section The Mixed Waste Management Facility Burial Ground was capped as mandated by a RCRA agreement between SRS and SCDHEC and officially closed in April 1991. The cap will be monitored and maintained for 30 years. 
Transuranic Waste Transuranic waste is radioactive waste contaminated with radionuclides that have decay rates and concentrations exceeding specified levels. It contains man-made elements heavier than uranium, thus the name trans (or beyond) uranium. Transuranic waste decays slowly and requires isolation for thousands of years. Equipment, tools, and protective clothing, such as laboratory coats and gloves, can become contaminated with transuranic radionuclides.

High-level Waste High-level waste is highly radioactive material resulting from the reprocessing of spent nuclear fuel. (Spent nuclear fuel is nuclear reactor fuel that has been irradiated to the extent that it can no longer effectively sustain a chain reaction.) High-level waste includes liquid waste produced directly in reprocessing and highly radioactive solid waste derived from the liquid that contains a combination of transuranic waste and fission products in concentrations high enough to require permanent isolation. It contains elements that decay slowly and remain radioactive for thousands of years. It also includes other highly radioactive material that the U.S. Nuclear Regulatory Commission, consistent with existing law, determines will require permanent isolation.

Low-level Waste Low-level waste is any radioactive waste not classified as highlevel waste or transuranic waste. It is generated by reactor operations, radionuclide production, medical procedures, and research and development projects. It typically has small amounts of radioactivity dispersed in large amounts of material. Examples of low-level waste include rags, papers, filters, tools, and protective clothing, such as laboratory coats.

Hazardous Waste Hazardous waste, as defined by RCRA, is any toxic, corrosive, reactive, or ignitable material that could negatively affect human health or could damage the environment. Environmental laws also list specific materials as hazardous waste and describe specific characteristics that classify a material as a hazardous waste.

Mixed Waste Mixed waste is a combination of radioactive and hazardous waste as defined by the Atomic Energy Act of 1954 and RCRA. Mixed waste is subject to RCRA, which regulates the hazardous component, and additional regulations governing the radioactive component.

Sanitary Waste Sanitary waste is neither radioactive nor hazardous. Solid sanitary waste is basically garbage and is disposed of in an off-site landfill; liquid sanitary waste includes sewage and industrial waste treated in on-site sewage treatment plants.

SRS has approximately 34 million gallons of high-level liquid radioactive waste containing about 600 million curies of radioactivity. An integrated approach has been developed to address the treatment, storage, and/or disposal of all site-generated waste. Near-term program emphases have been placed on the construction and startup of new facilities for the solidification, including vitrification, of highlevel liquid waste; the treatment of some stored waste in preparation for future permanent storage at a federal repository; and the incineration of low-level, hazardous, and mixed wastes. 


\section{National Environmental Research Park}

In 1972, the Atomic Energy Commission designated the site as the nation's first National Environmental Research Park. The park provides a variety of unusual opportunities to study the interaction between a nuclear industrial site and the environment. In addition, over 14,000 acres ( 7 percent) of SRS land is specifically protected for research. These areas, designated as set-aside areas, provide undisturbed land for comparison with areas affected by site operations and forest management. Because public access to the site is limited, rare opportunities exist for long-term research programs, which can be conducted without the disturbances that may occur in unrestricted areas. National Environmental Research Park activities are conducted by and coordinated through the Savannah River Technology Center (SRTC), the Savannah River Ecology Laboratory (SREL), the Savannah River Forest Station (SRFS), and the Savannah River Archaeological Research Program (SRARP).

SRTC, a research and development facility at SRS, provides support to many onsite operations. Many research and development activities conducted by SRTC are designed to meet environmental and other compliance requirements. Projects include the radiation assessment program, the calculation of dose uncertainties, the meteorological monitoring program, and the development and testing of new equipment.

SREL is operated by the University of Georgia under contract with DOE. SREL has conducted independent environmental studies of SRS, surrounding streams and ponds, and the Savannah River since 1951. Studies focus on research activities involving freshwater and terrestrial ecosystems in natural and disturbed habitats as well as biological inventories, competition in plant and animal communities, and the use of radioactive tracers to determine food chains. For more information, contact SREL at 803-725-2472.

SRFS was formed in 1952 when the Atomic Energy Commission and the U.S. Department of Agriculture's Forest Service formed an interagency agreement to create a forest management organization at SRS. SRFS has expanded from strictly timber management to the management of all site natural resources. This includes wildlife, fish, and botany studies; management for threatened, endangered or sensitive wildlife and plant species; protection of soil and watershed quality; and efforts to maintain a healthy forest for environmental research. For more information, contact SRFS at 803-725-2441.

SRARP began in 1973 under a cooperative agreement with DOE and the South Carolina Institute of Archaeology and Anthropology, University of South Carolina. The primary function of SRARP is to provide DOE with recommendations concerning archaeological matters to facilitate the management of archaeological resources at SRS. Other functions of SRARP include cultural resource management, research, and public education as well as compliance activities involving reconnaissance surveys, general intensive watershed surveys, specific intensive surveys, data recovery, and coordination with major land users. For more information, contact SRARP at 803-725-3623. 


\section{Keeping Up-to-Date with Environmental Issues at SRS}

SRS publishes a newsletter, the Environmental Bulletin, to notify the public of opportunities for involvement in site environmental cleanup and compliance activities. For information, contact

Ms. Becky Craft, DOE

Savannah River Operations Office

Office of External Affairs

803-725-2889
Mr. Mark Musolf, WSRC

or treach 803-644-1814

In addition, the EPA and SCDHEC call for public involvement and notice when a change is made to one of the RCRA permits, including applications and modifications. The original permit and proposed modifications can be reviewed at the DOE Public Reading Room at the library of the University of South Carolina-Aiken.

\section{Touring SRS}

The SRS Visitors Program provides the public with a firsthand look at the site and its activities. Visitors to the site may take a drive-by tour of the site and may enter some facilities. Each tour is designed to meet the needs and interests of the visiting group.

The program is open to all U.S. citizens at least 16 years of age. A minimum of 10 people is requested per tour. Groups will be asked to provide names, home addresses, and social security numbers of each visitor in advance, and each visitor must bring a photo identification. The tour coordinator will try to accommodate special requests for dates and times, but no tours are conducted on weekends or holidays. Requests must be made at least 60 days before the desired date. To arrange tours, contact

Westinghouse Savannah River Company Media and Community Relations Department $992-4$ W, Room 225 1995 South Centennial Ave. Aiken, South Carolina 29803

Phone: 803-644-6816 


\section{References}

1. RCA Service Company, Atomic Radiation, 1957, Radio Corporation of America.

2. National Council on Radiation Protection and Measurements, Ionizing Radiation Exposure of the Population of the United States, NCRP Report No. 93, 1987.

3. Subcommittee on Risks of Low-Level lonizing Radiation, Low-Level Radiation Effects: A Fact Book, 1985. The Society of Nuclear Medicine, Inc.

4. National Cou' icil on Radiation Protection and Measurements, Exposure of the U.S. Population from Diagnostic Medical Radiation, NCRP Report No. 100, 1989.

5. U.S. Department of Energy Order 5400.5, "Radiation Protection of the Public and the Environment," 1990.

6. American Nuclear Society, Nuclear Energy Facts Questions and Answers, 1988.

7. National Council on Radiation Protection and Measurements, Exposure of the U.S. Population from Occupational Radiation, NCRP Report No. 101, 1989.

8. U.S. Environmental Protection Agency, Manual of Protective Action Guides and Protective Actions for Nuclear Incidents, EPA-520/1-75-001, 1975 (revised 1980).

9. U.S. Nuclear Regulatory Commission, "Standards for Protection against Radiation," Title 10 Code of Federal Regulations Part 20.

10. U.S. Department of Energy, "Occupational Radiation Protection," Title 10 Code of Federal Regulations Part 835.

11. Committee on the Biological Effects of lonizing Radiations, 1990, Health Effects of Exposure to Low Levels of lonizing Radiation BEIR V, 1990, National Academy of Sciences.

12. Cember, Herman, Introduction to Health Physics, 1983, Pergamon Press, Inc.

13. National Council on Radiation Protection and Measurements, Exposure of the Population in the United States and Canada from Natural Background Radiation, NCRP Report No. 94, 1987. 


\section{Additional documents used in the preparation of this pamphlet}

Davis-Besse Nuclear Power Station, 1992, Annual Environmental Operating Report for Davis-Besse Nuclear Power Station January 1, 1991 to December 31, 1991, Toledo Edison Company, Toledo, Ohio.

Hall, Eric J., 1976, Radiation and Life, Pergamon Press, New York, N.Y.

International Atomic Energy Agency, 1987, Facts About Low-Level Radiation, American Nuclear Society, La Grange Park, III.

International Atomic Energy Agency, 1989, Radiation-A Fact of Life, American Nuclear Society, La Grange Park, III.

Lillie, David W., 1986, Our Radiant World, The lowa State University Press, Ames, lowa.

National Radiological Protection Board, 1989, Living with Radiation, Her Majesty's Stationary Office Publications Centre, London, England.

Subcommittee on Nuclear Terminology and Units, 1986, Glossary of Terms in Nuclear Science and Technology, American Nuclear Society, La Grange Park, III.

Technical Steering Panel of the Hanford Environmental Dose Reconstruction Project, Fact Sheets, Technical Steering Panel, Olympia, Wash.

U.S. Council for Energy Awareness, 1991, Radiation in Perspective, U.S. Council for Energy Awareness, Washington, D.C.

Office of Environmental Restoration and Waste Management, 1991, Environmental Restoration and Waste Management (EM) Program-An Introduction, DOE/EM-0013P, U.S. Department of Energy, Washington D.C.

Office of Environmental Restoration and Waste Management, 1991 and 1992, Fact Sheets, U.S. Department of Energy, Washington D.C.

Borosilicate Glass, DOE/EM-0074P

Defense Waste Processing Facility, DOE/EM-0034P

Environmental Restoration Activities at Savannah River Field Office, DOE/EM-0050P

Hazardous Waste, DOE/EM-0020P

Mixed Waste, DOE/EM-0021P

Perspective on Radioactivify, DOE/EM-0064P

Radiation in the Environment, DOE/EM-0065P

Radioactive Waste, DOE/EM-0019P

Waste Management Activities at Savannah River Field OHfice, DOE/EM-0033P

What is Environmental Restoration?, DOE/EM-0067P

What is Waste Management?, DOE/EM-0066P 

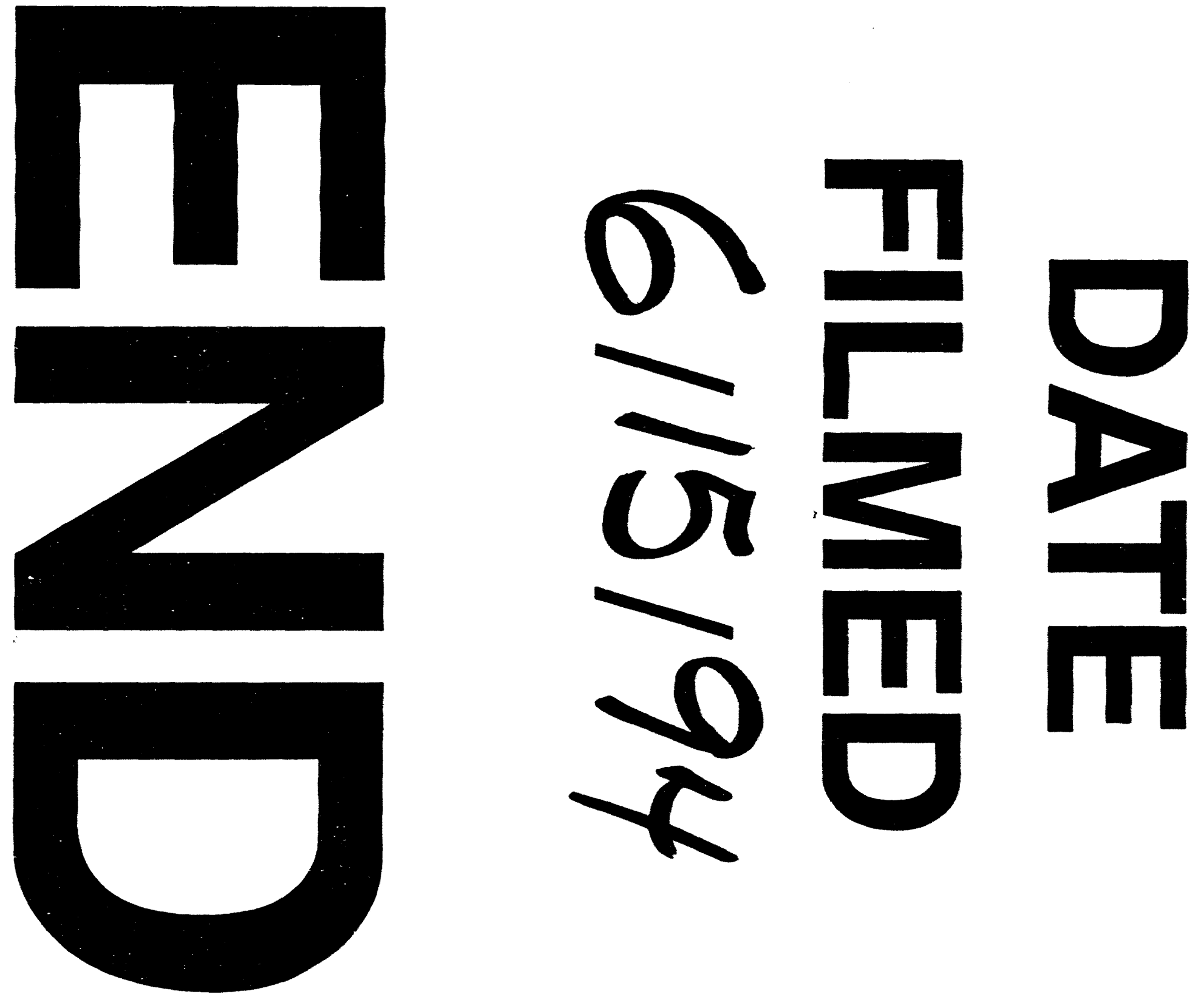


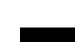

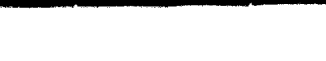

